\title{
Process Evaluation on Medical Record Reporting and Information Usage Iskandar Muda Hospital Nagan Raya Regency
}

\author{
Oka Sahrana, Safrizal, Dian Fera, Arfah Husna
}

Faculty of Public Health, Universitas Teuku Umar, Indonesia

Corresponding author: Oka Sahrana, e-mail: okasahrana01@gmail.com

Co-author : S: safrizal@utu.ac.id, DF: dianfera@utu.ac.id, AH: arfahhusna@utu.ac.id

Submitted:08/06/2021 Revised: 21/09/2021 Accepted: 27/09/0000 Published online: 22/10/2021

\begin{abstract}
Doi: https://doi.org/10.35308/j-kesmas.v7i2.3669 How to cite this article: Sahrana, O., Safrizal \& Fera, D (2021). Process
Evaluation on Medical Record Reporting and Information Usage Iskandar Muda Hospital Nagan Raya Regency. J-Kesmas :

Jurnal Kesehatan Masyarakat (The Indonesian Journal of Public Health). 8(2): 79-85.
\end{abstract}

\begin{abstract}
Medical records are all records and documents about the patient's identities, examinations, treatments, actions and other services provided to the patient. Reporting medical records at Iskandar Muda hospital still does not follow standards. This is due to the lack of discipline of officers in filling out medical records, lack of medical records of officers and related health workers, then also influenced by the Hospital Management Information System that does not yet exist. The purpose of the study was to evaluate the reporting of medical records at Sultan Iskandar Muda hospital. This study uses qualitative research. The results showed that Sultan Iskandar Muda Hospital has been processing medical record data. The procedure of making a report that is not appropriate is the completion of resumes and daily census pain hospitalization. While the proper methods are a recapitulation of outpatient visits, making reports of hospital activities and making morbidity reports of inpatients and outpatients. The medical records unit has produced internal and external reports following the guidelines, and middle-level hospital management has fully used medical record information. It can be concluded that in processing medical record data, there are some obstacles. The procedure of making a report is not following the guidelines, and medical record information has been fully utilized.
\end{abstract}

Keywords: Evaluation; Information; Medical Records; Reports

\section{Introduction}

Decree No.269/MENKES/PER/III/2008 on medical records contains records and documents about the patient's identity, examination, treatment, actions, and other services provided to the patients. According to WHO (2006), medical records are essential for patients, present and future health services. In addition, medical records are also used in the management and planning of facilities and services from health services, medical research, and making health care statistics. Based on Decree No. 269/ MENKES/III/PER/2008, the purpose of medical records is to actively assist the administration's achievement to implement efforts to improve health services in hospitals.

The evaluation was conducted by comparing the process of making a report at Sultan Iskandar Muda Hospital in Nagan Raya Regency with guidelines for the Implementation of Medical Records of Hospitals in Indonesia Revision II (Ministry of Health, 2006) and Juknis (Hospital Information System) SIRS (Kemenkes RI, 2011). If not evaluated from a medical record will have an impact on the quality of a hospital. According to Sanggamele (2018), the management of medical records in hospitals supports the achievement of the best administration to achieve the hospital's goal, namely improving the quality of health services in hospitals. In managing medical records to keep the quality of services for hospitals, the management of medical records must be effective and efficient. According to Budi (2011), good reporting of medical records will improve health services in hospitals.

Based on the results of and ani and Rochmah (2013) research, Usada Sidoarjo Hospital has processed medical record data consisting of Assembling, Coding, Indexing, and making reports. In carrying out resume completion procedures, daily census procedures of inpatients, procedures for making inpatient and outpatient morbidity reports, and external hospital reports produced by the Medical Record Unit of Usada Sidoarjo Hospital are included in the category of less suitable. The implementation of outpatient visit recapitulation procedures, procedures for making hospital activity reports, and internal hospital reports in the Medical Record Unit of Usada Sidoarjo Hospital are appropriate.

Sultan Iskandar Muda Hospital is a general hospital type $\mathrm{C}$ in Nagan raya Regency. This hospital is one of the goals of the community in obtaining complete 
health services. Based on our observations and interviews, the results of medical records conducted by the hospital health services section are incomplete. This is due to the lack of medical personnel, resulting in coding processes, verification/Indexing, data entry is not following standards in the procedure of making a report that becomes an obstacle, namely the lack of discipline when both doctors and nurses in filling out medical records. Lack of Human Resources, both medical record officers educated in medical records and other officers and inadequate facilities such as SIMRS (Hospital Management Information System) do not yet exist.

\section{Methods}

This type of research uses qualitative research methods. This research was conducted at Sultan Iskandar Muda Hospital of Nagan Raya Regency. Researchers asked permission to research the Director of Rsud Sultan Iskandar Muda. By providing a research letter from the institution/campus and explaining why the researchers conducted the study so that the hospital was confident and gave permission to conduct research related to the topic.

The study was conducted in January 2021. With an informant of 6 people, consisting of the Head of the Medical Record Room, Reporting Officer, Supporting
Service Officer, 2 Medical Record Officers and NonMedical Support.

\section{Results}

\section{Medical Record Data Processing}

The process of processing medical record data at Sultan Iskandar Muda Hospital includes assembling, Coding, verification / Indexing, and making reports. Processing medical record data starting from building, the task of the recording officer is only to check the completeness. Then coded for the filing of his claim, his claim is precisely the use of National Health Insurance. After being coded, the patient data is done, and verification is carried out to re-examine the information that has been inputted. After that, the officer makes a report based on medical record data through these stages. In processing the medical record data that we do, we found some problems, including the lack of medical records files caused by the lack of medical personnel. If this is allowed, it will hamper the examination of medical track records, resulting in difficulties during the BPJS claim (Social Security security organizer guarantee). However, in providing disease codes, Sultan Iskandar Muda hospital already uses and applications ICD-10 for diagnosis code and ICD-9 for medical action following the coder rules.

Table 1. Medical Record

\begin{tabular}{lccl}
\hline Medical Record & \multicolumn{2}{c}{ Implementation } & Information \\
\cline { 2 - 3 } & No & Yes & \\
\hline Assembling & & $\checkmark$ & $\begin{array}{l}\text { Checking the completeness of recording } \\
\text { medical record files }\end{array}$ \\
Coding & $\checkmark$ & The process of administering disease codes \\
Verifikasi/index & & $\checkmark$ & Re-examination of data that has been inputted \\
Report creation & & $\checkmark$ & Internal and external hospital report generation \\
\hline
\end{tabular}

(Primary Data, 2021)

\section{Evaluation of The Process of Making Reports and Medical Record Information}

According to Sailendra (2015), Standard Operating Procedure is a set of written instructions used for routine activities or activities that an organization repeatedly carries out. Sultan Iskandar Muda Hospital has implemented a Standard Operating Procedure
(SOP) following the guidelines. However, in carrying out these procedures, there are some obstacles. However, it is not a reason for a hospital to improve/improve performance so that medical records can run following the guidelines.

The procedure of making a medical record report consists of the completion of a resume, daily census of inpatients, recapitulation of outpatient visits, the creation of hospital activity reports and the creation of inpatient and outpatient morbidity reports. The reportmaking process is assessed by interviewing officers 
and directly observing the Medical Record Unit's report-making function. The medical record information generated at Sultan Iskandar Muda Hospital is an internal report and an external hospital report.

\section{Resume Completion Procedure}

The doctor writes resumes after the patient is given the service. The job of the medical record officer is only to check the completeness. The summary must be filed within $1 \times 24$ hours after the patient is given the service, and the incomplete resume is returned to the doctor or health worker concerned for $2 \times 24$ hours. After the resume completion period ends, the summary will be carried by a medical record officer and put into storage. There are several obstacles in the completion of resumes, namely the completion of resumes is not on time, due to time constraints and the many activities of doctors and officers, so that resumes are not filled as soon as possible. The procedure for completing the summary of Sultan Iskandar Muda Hospital is not following the guidelines for the Implementation of Medical Records of Hospitals in Indonesia Revision II (Ministry of Health, 2006).

\section{Daily census procedure of inpatients}

Census collection is conducted every day, but there is a shortage of officers, causing time inaccuracies in the daily census collection of inpatients. The obstacles are that medical records officers do not collect daily censuses from the treatment room every day, nurses do not deposit daily censuses to the Medical Record Unit. The task of the medical record officer is only to process the results of the daily census of inpatients every month. The daily census procedure of inpatients is not following the guidelines for the Implementation of Hospital Medical Records in Indonesia Revision II (Ministry of Health, 2006).

\section{Outpatient Visit Recapitulation Procedure}

The procedure recapitulation of outpatient visits, data collection is done manually. The registration section already uses a computerized system by using the Virtual Claims application to enter patient data. The medical record unit takes outpatient visits from the registration section every day, then recap every day and is done every month. Demonstrate the procedure recapitulation of outpatient visits following the guidelines for the Implementation of Medical Records of Hospitals in Indonesia Revision II (Ministry of Health, 2006).

\section{Hospital Activity Report Creation Procedure}

In the procedure of making a report on hospital activities, Sultan Iskandar Muda Hospital has collected data on hospital activities from hospitalization and outpatient. The data will be processed into information on hospital activities. The hospital's internal report was submitted to the Head Section Non-Medical Support, Supporting Services Program. Furthermore, the external world was introduced to the Central Dinkes (Kemenkes RI), Provincial Dinkes and District / City Dinkes. Showing that the procedure of making a report on hospital activities following the guidelines for the Implementation of Hospital Medical Records in Indonesia Revision II (Ministry of Health, 2006) Juknis (SIRS) Hospital Information System (KKEMENKES RI, 2011).

\section{The procedure of Making Morbidity Report of Inpatients and Outpatients}

The morbidity report creation procedure is taken from inpatient and outpatient data classified into the top 10 diseases, which are reported once a month every 15th to the Ministry of Health (Central Dinkes), Provincial Dinkes and District/city Dinkes. (Ministry of Health, 2006).

Table 2. Evaluation Results of The Process of Making Reports and Medical Record Information

\begin{tabular}{clc}
\hline No & \multicolumn{1}{c}{ Evaluation } & Information \\
\hline 1. & Medical Record Report Creation Procedure & \\
& Resume completion procedure & Inappropriate \\
& Inpatient daily census procedure & Inappropriate \\
& Outpatient visit recapitulation procedure & Appropriate \\
& Procedure for making hospital activity reports & Appropriate \\
& Procedure for making morbidity reports of inpatients and outpatients & Appropriate \\
2. & Medical Record Information & \\
& Internal hospital report & Appropriate \\
& Hospital external report (SIRS Online) & Appropriate \\
\hline
\end{tabular}

(Primary Data, 2021) 


\section{Internal Reports and External Reports}

Sultan Iskandar Muda Hospital Medical Record Unit has produced internal reports and external hospital reports following the guidelines. The creation of internal and external depictions of data is taken from inpatient and outpatient service activities. Internal reports include incoming patients, patients out, patients who died, length of care of patients treated, days of patient care in hospital, use of beds (BOR), childbirth, surgery, and poly or outpatient. At the same time, the external report is SIRS Online which is sent to the Ministry of Health (Central Dinkes), Provincial Dinkes, and District / City Dinkes. The manufacture of the report is still manually because Sultan Iskandar Muda Hospital does not have SIMRS (Hospital Management Information System), at that time still wants locking.

Based on interview footage with one of the following informants:

What are the obstacles in creating internal and external reports?

"The obstacle? We are still manual. Because we do not have SIMRS yet. We still want to launch but not yet, because we have no computer yet, still manual. That is what I said in the manual report. When I got the new manual, I went online. If you already have SIMRS, Kan twice works once the patient enters, recorded in the report. If we are just a report, we need what report, that is. So here, there is no SIMS. So still, the manual is all written."

\section{Utilization of Medical Record Information}

How to find out the utilization of medical record information is done by interviewing the Head of Supporting Services and Kasi Supporting NonMedical, which is an influential acting hospital, who knows all about medical record information.

The Administrative Department (TU) receives the hospital's internal report information. The form of utilization is suffocating, checking all reports in the hospital, reporting and ordering other fields to carry out their functions. The General and Staffing section of the type of information received is the number of patient visits. The form of report utilization is to know the number of patient visits than the number of workers who handle patients to perform the work following the presence of employees/staff in the hospital.

The Finance Department receives information on the number of patient visits. The form of death is by knowing the number of patient visits, and it can be known the payment of medical services. The more the number of patient visits, the more costs received by officers. The Program Preparation, Evaluation and Reporting section receives internal hospital reports and service indicators, including BOR, TOI, LOS, BTO, GDR, and NDR. The form of filing reports related to hospital needs includes planning for the next year, including the budget provision for hospital needs in performing services.

The Support Services section receives internal hospital reports that include hospitalizations, outpatients, top 10 diseases, including supporting needs with medicine, nutrition and laboratories. After being reported, information utilization can meet all hospital needs, both in-service needs and support needs. The Medical Services section receives information on the top 10 diseases. The form of data utilization is knowing the top 10 diseases; medical services can increase the needs of medical services such as doctors' provision and tools' provision so that all requirements are met in performing medical services.

The Nursing section receives inpatient service indicator information such as BOR (Bed Occupational Rate), provision of beds. The form of utilization of report is to determine the unit cost of the length of patient care - the more beds and the size of patient care, the more nurses' workload in performing services. However, the more the workload of nurses, the more incentives received by them.

Table 3. Utilization of Medical Record Information

\begin{tabular}{|c|c|c|c|}
\hline \multirow{2}{*}{ Position } & Utilization & \multirow{2}{*}{ Types of Information } & \multirow{2}{*}{ Forms of Utilization } \\
\hline & Yes & & \\
\hline $\begin{array}{l}\text { Administration } \\
\text { (TU) }\end{array}$ & $\checkmark$ & Internal reports & $\begin{array}{l}\text { Check and report all reports in the } \\
\text { hospital }\end{array}$ \\
\hline $\begin{array}{l}\text { General And } \\
\text { Staffing Section }\end{array}$ & $\checkmark$ & Number of patient visits & $\begin{array}{l}\text { Implementation of work on the } \\
\text { continuity of the presence of hospital } \\
\text { staff/employees }\end{array}$ \\
\hline $\begin{array}{l}\text { Finance } \\
\text { Department }\end{array}$ & $\checkmark$ & Number of patient visits & Payment of medical services \\
\hline
\end{tabular}


Pro drafting,

Evaluation and

reporting section

Support Services

Department

Medical Services

Department

Nursing

Department $\checkmark \quad$ Internal reports and

service indicators

$\checkmark \quad$ Internal Reports

Top 10 diseases

Inpatient service

indicator (BOR)
Planning, Budgeting and Submission of reports on hospital needs.

Meet support needs, such as medicine, nutrition and laboratories

Improved medical services needs

Determination of unit cost and workload of nurses

(Primary Data, 2021)

\section{Discussion}

\section{Medical Record Data Processing}

Sultan Iskandar Muda Hospital has processed data that has gone through the process of Assembling, Coding, verification/index, and making reports.

1. Assembling is the process of assembling or sorting pages of medical records files. In this process, an analysis is carried out to see the completeness of the medical record file. If there is an incomplete medical record file, the medical record unit returns the medical records to the medical officer (Budi, 2011).

2. Coding is the process of Coding on the diagnosis of disease and medical action. The code used is provided by the World Health Organization (WHO) in ICD-10 and ICD-9 CM. ICD-10 is used to clarify diagnosis or disease, while ICD-9 is used for medical measures (Budi, 2011).

3. Indexing is the process of creating tabulations according to the code created in the index card.

4. Reporting is the process of making a report for the internal and external interests of the hospital.

There are several obstacles in processing medical record data, including the lack of completeness in the medical record file, because doctors or health workers do not fill out complete medical records when patients are given services, and time constraints. Then, in the assembling section, there is a lack of officers. The medical record file accumulates, which causes the examination of medical records in the Assembling, and other parts will also be hampered. When data processing is impeded, it will significantly affect the detection of BPJS (Social Security Organizing Agency). It will also affect hospital reporting statistics and cause officers difficulty in analyzing medical records. Medical records should be filled in immediately within $1 \times 24$ hours after the patient is given the service.
Doctors and health workers should fill in medical records. When the medical history is in the content immediately, the things that want to be written will be filled all in the medical form, both his diagnosis and medical action. And in the assembling section the shortage of officers. Therefore, Human Resources is needed to examine the completeness of medical record recording that is not accumulated and delayed.

It is necessary to educate doctors and officers about the importance of filling medical records quickly and accurately. Then to do the addition of HUMAN RESOURCES (Human Resources) so that the filling of medical records is done in a timely and accurate manner. According to Ilyas (2011), The hospital's HR planning should be based on the function and workload of services that will be faced in the future, intended so that the process of the hospital can run well.

Wijaya research (2019) incomplete medical record documents will cause health workers difficulty recognizing the patient's disease history and claims to the insurance.

\section{Evaluation of The Process of Making Reports and Medical Record Information}

In the resume completion procedure, there are several obstacles, namely in the completion of resumes are not on time, due to time constraints and the many activities of doctors and officers so that the summary is not filled as soon as possible. Completion of resumes in this hospital occurs delays even up to 5 days. Therefore, it is necessary to socialize doctors and health workers to comply with regulations and correctly carry out their obligations. Completeness of filling out a medical resume indicates a doctor's compliance to complete a medical summary. According to Azwar (2005), a person is said to be obedient if he can understand, realize, and carry out the rules that have been set without any coercion from anyone. This can be demonstrated by the actions of doctors willing to comply with regulations and policies 
that the hospital has developed, such as filling out a complete medical resume after the patient goes home and writing a diagnosis following ICD-10.

Medical records officers do not collect daily censuses of inpatients every day. In census collection, the occurrence of delays. The census should be given to the medical records unit every day by nurses from the nursing room. This is why room nurses do not deposit a daily census of hospitalization to the medical record unit due to lack of officers and absence of room admission, and a large workload that makes medical record officers hampered in the collection of daily census inpatients.

The impact of delays in census collection could slow the creation of hospital reporting statistics. Dining research (2015) states that the constraints of the continuous daily census of hospitalization will affect the late calculation of non-indicator statistics of hospitals and can also inhibit the process of financial disbursement. The cause of the delay in census collection is also caused by the lack of responsibility of officers in filling out the daily census of hospitalizations, and the workload is not following the number of officers, which results in low work productivity and the requirement to affect the quality of hospital services.

The recapitulation of outpatient visits, the creation of hospital activity reports, and morbidity reports of inpatients and outpatients have been carried out following the Implementation guidelines of Hospital Medical Records in Indonesia Revision II (Ministry of Health, 2006). Nevertheless, there are some obstacles in producing internal reports and external reports, namely the occurrence of delays in providing internal reports to hospital management due to late in the rooms because the creation of the account is still manually. Then Sultan Iskandar Muda Hospital does not yet have a Hospital Management Information System (SIMRS). According to PERMENKES Number 82 of 2013 mentioned that every hospital must hold SIMS. Because SIMRS (Hospital Management Information System) can help reduce the workload of officers and can assist in providing administrative services and the creation of hospital reports.

\section{Utilization of Medical Record Information}

In general, the benefits of medical records are contained in Decree No. 269 / MENKES / PER / III / 2008 Article 13, namely (1) Maintenance of health and patient care, (2) Evidence in law enforcement processes, medical disciplines, and dentistry and enforcement of medical ethics, (3) Educational and research needs, (4) Basic payer of health care costs, (5) Health statistics data.

All middle levels of Sultan Iskandar Muda Hospital have utilized medical record information, including Administrative (TU), General and Staffing, Finance, Program Preparation, Evaluation and Reporting, Supporting Services, Medical Services, and Nursing. The form of information utilization is the indicator of hospitalization (BOR), the number of inpatient and outpatient visits, the top 10 diseases, tools, supporting needs such as drugs, nutrition, laboratories, etc. Medical record information is helpful for planning and programs in meeting all the hospital's needs in providing services to patients and as an evaluation material in improving hospital performance for one year.

\section{Conclusion}

Sultan Iskandar Muda Hospital has several obstacles in processing medical record data, including the lack of completeness of medical record files. Doctors and workers do not immediately fill out medical record files after the patient is given services. The lack of medical record officers in the assembling section, so the completeness of medical record-keeping examinations piled up and hampered so that the Assembling, Coding, verification/indexing, BPJS claims, and reporting statistics will also be hampered.

Evaluation of the process of making reports and medical record information of inappropriate procedures is the completion of resumes and daily census of inpatients. While the appropriate methods are a recapitulation of outpatient visits, making reports of hospital activities and making morbidity reports of inpatients and outpatients. RSUD Sultan Iskandar Muda has produced internal reports and external reports (SIRS Online) following the guidelines. Middle-level management of RSUD Sultan Iskandar Muda has fully utilized medical record information, including TU, General and Staffing, Finance, Program Preparation, Evaluation and reporting, Support Services, Medical and Nursing Services.

\section{Acknowledgement}

This research can be done well with the help of various parties. Thank you to RSUD Sultan Iskandar Muda Nagan Raya Regency for helping and allowing this research. 


\section{Author Contribution}

The authors' contributions to this study are collecting in-depth interviews, analysing results, and compiling scripts.

\section{References}

Andani, T and Rochmah T.N. (2013). Evaluation of the Process of Making Reports and Utilization of Medical Record Information at Sidoarjo Business Hospital. Journal of Indonesian Health Administration. Volume 1 Number 4 SeptemberDecember 2013.

Budi, S.C. (2011). Medical Record Work Unit Management. Yorgyakarta: Quantum Synergistic Medical.

Ministry of Health. (2006). Guidelines Implementation and Procedure of Hospital Medical Records in Indonesia (Revision II). Jakarta: Directorate General of Medical Services.

Depkes RI. (2006). Pedomam Penyelenggaraan dan Prosedur Rekam Medis Rumah Sakit di Indonesia (Revisi II). Jakarta: Direktorat Jenderal Bina Pelayanan Medik.

Diningrat, F.C, and Sugiarti, I. (2015). Factors delayed return of daily census hospitalization at Kab. WHO. (2006). Medical Record Manual: A Guide For Developing Countries. Philippines: WHO.

Wijaya, L. (2013). Destruction of Medical Records. Jakarta: Esa Unggul.
Ciamis Hospital. Indonesian Journal of Health Information Management, Vol.3 No.2 October 2015.

Ilyas, Yaslis. (2011). Performance, Theory, Assessment and Palatihan. Jakarta: BP. KKUM UI.

Kementeri Kesehatan RI. (2008). Peraturan Menteri Kesehatan Republik Indonesia, Nomor 269/MENKES/PER/III/2008 Tentang Rekam Medis. Menkes RI. Jakarta.

Permenkes RI Nomor 1171 Tahun 2011 Tentang Sistem Informasi Rumah Sakit. Menkes RI: Jakarta.

Permekes RI Nomor 82 Tahun (2013) Tentang Sistem Informasi Manjemen Rumah Sakit. Menkes RI : Jakarta.

Sailendra, A. (2015). Practical Steps to Create an SOP. Yogyakarta: Trans Idea Publishing.

Sanggamele C, Kolibu F. K, and Maramis, F. R. R. (2018). Analysis of Medical Record Management at Umun Pancaran Kasih Manado Hospital. Journal of Kesmas, Vol.7, No.4.

RSUD Sultan Iskandar Muda Tahun (2020). Profil RSUD Sultan Iskandar Muda. Nagan Raya 